Research Article

\title{
ORGANIC MATERIAL POTENTIAL AND ENERGY ANALYSIS FOR BIOGAS APPLICATION OF BATMAN
}

\author{
Muhammed Enis YILDIZ ${ }^{1}$, Özbay ÇAĞIRTEKİ ${ }^{2}$, Adem YILMAZ
}

\begin{abstract}
With the decrease of fossil fuels in the world, increasing energy costs caused the countries to turn to different kinds of energy sources. One of these sources is biogas energy which is a renewable energy source. Biogasorganic is a kind of energy resulting from the fermentation of domestic and industrial wastes indoor environment.

In this study, biogas amounts and energy analysis which can be obtained by determining the potentials of organic (animal and herbal) wastes belonging to Batman province have been made. As a result of the researches, $52 \%$ of the total wastes in the province of Batman are composed of organic wastes. According to the data obtained in the calculations; It has been found that the biogas production potential in Batman province is $115,745 \mathrm{~m}^{3} /$ day biogas and 544,000 KWh / day electrical energy from the wastes and $1.563 \mathrm{~m}^{3} /$ day biogas and $7.346 \mathrm{KWh} /$ day electrical energy from the vegetable wastes. The obtained data are given in table and graph
\end{abstract}

Key words: Biogas, Fermentation, Animal Waste, Herbal Waste

\section{INTRODUCTION}

Nowadays, it is seen that fossil fuels are gradually decreasing and countries are turning to renewable energy sources within the scope of their efforts to diversify their energy needs. Biagas which does not harm to environment is seen as a renewable energy source cause it can be obtained continuously in nature. Biogas energy, agriculture and livestock activities as a result of the production of vegetable and animal waste produced by biogas production facilities by oxygen-free respiration (fermentation) by bacteria is broken by the resulting methane $\left(\mathrm{CH}_{4}\right)$ is used as fuel and energy products. It's also evaluate that like as a result of fermentation in fertilizers for use in agriculture.

As a result of the reduction in natural energy resources and the search for new resources, biogas production from organic wastes is considered as an alternative source. The use of organic wastes in the production of biogas is an effective waste management step in both waste disposal and energy generation.[1]

Biogas is a colorless, flammable gas, depending on the structure and process of organic matter, containing $60-70 \% \mathrm{CH}_{4}, 30-40 \% \mathrm{CO}_{2}$ and low amount $\mathrm{H}_{2} \mathrm{~S}, \mathrm{~N}, \mathrm{H}, \mathrm{CO}$. The fuel equivalent of biogas is 0.60-0.65 $\mathrm{L}$ petroleum / $\mathrm{m}^{3}$ biogas [2],[3].

\footnotetext{
${ }^{1}$ Graduate School Of Natural And Applied Sciences /Batman University (mymenis@hotmail.com) (Dhttps://orcid.org/0000-0002-7276-6385

${ }^{2}$ Graduate School of Natural And Applied Sciences /Batman University (ozbaycagirtekin@hotmail.com) 1 https://orcid.org/0000-0002-98124268

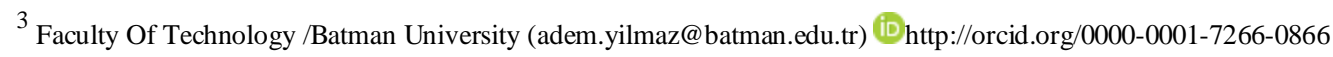


It is important to evalute that biomass energy, which is one of the renewable energy sources, has increased in recent years, increase in utilization rates, and within the scope of energy efficiency applications and the diversity of energy resources. For this purpose, there are various breakthroughs in the world. In the coming years, it is predicted that the biofuel products that will be obtained with the conversion of traditional biomass to the bioenergy in modern facilities will have an important place among the renewable energy sources. [4]

In our country, animal manure is burned for heating and cooking purposes. The use of animal manure in agricultural production is more economical than conversion to energy. Animal manure has superior properties than artificial fertilizers. It is possible to prevent the incineration of animal manure and to give it to the agricultural land by giving a new energy to the rural area to replace this energy. This energy is biogas that can be obtained from animal manure.[5]

Which can be related to the biomass potential that exists in our country with statistical data of Turkey's annual biomass potential of about 32 MTOE, while total converted to bioenergy potential is said to be about 16.92 MTOE. [6] 73 units in Turkey biogas, biomass, waste heat and power plant pyrolysis oil. The total installed capacity of these power plants is approximately 395.0 MW. [7]

Considering the studies on the use of biogas energy; The biogas energy produced from animal wastes in our country shows that the energy value is between 3 and 3.5 billion $\mathrm{m}^{3} /$ year. [8]. If the biogas potential of urban solid wastes is 4,850 million $\mathrm{kWh} /$ year and $1 \%$ of the processed agricultural land is used for energy plant cultivation, ir is determined that the biogas potential will be 25.95 billion $\mathrm{kWh} /$ year and that the biogas potential of animal manure will be 14.26 billion $\mathrm{kWh} /$ year [9]. The annual biogas energy potential for animal waste originating from Iğdır city is estimated to be 21.441 million $\mathrm{m}^{3}$ [10]. It has been shown that approximately $87,645 \mathrm{~m}^{3} /$ daily biogas can be produced from biogas plants from animal manure in Malatya. [11]. When the theoretical biogas energy value which can be produced from organic wastes for Ankara city is considered as $\mathrm{m} 3$ / day, it is found as $277.348 \mathrm{~m}^{3}$ / daily from animal wastes, $38.493 \mathrm{~m}^{3} /$ daily from agricultural wastes and $160.380 \mathrm{~m}^{3} /$ daily from kitchen wastes [12].

In Batman province, agricultural activities have gained importance with the development of irrigation conditions as well as animal husbandry. In many fields wheat, corn and lentil cereal products are planted. However, after harvesting the crops, unfortunately, the remaining stubbles are burned unconsciously and they endanger human health while damaging the environment and natural life. While many land becomes a flame ball, an important energy source is wasted in front of us.

Batman province has a significant waste potential both in livestock and agriculture and their evaluation is of great importance both for the solution of environmental problems and for alternative energy sources.

\section{METHOD}

Statistical data and web pages were used to determine the amount of organic waste in Batman province. The different data obtained have been brought into tables and graphs. The collected data were calculated by using scientific calculations and transformations. Biogas potential and daily / yearly energy analyzes were calculated from animal and vegetable wastes in Batman province. While the data were collected, the changes in the last few years were taken into consideration. Calculations have been made by taking into account the serious decreases and increases that may occur in years.

In order to calculate the amount of fertilizer to be formed from animal wastes, animal manure production volume (ton / year) and the amount of biogas $\left(\mathrm{m}^{3} /\right.$ year) that can be obtained are given according to animal species. The electrical energy that can be produced on an annual basis according to the amount of $4.70 \mathrm{kWh}$ electricity corresponding to $1 \mathrm{~m} 3$ biogas is calculated. Energy production potentials which are mixed with the amount of biogas obtained from agricultural wastes are calculated daily and yearly. 
The energy value of methane gas obtained from cattle, sheep and poultry and the amounts of energy that can be taken from agricultural wastes are shown as numerical data, graphs and tables.

\section{DISCUSSION}

When the amount of solid waste in Batman province is examined, organic wastes constitute the biggest share with $52 \%$. Organic waste is divided into two different categories. The first is animal waste. These are the wastes of cattle, sheep and poultry and slaughter waste. The second is herbal waste. These are straw, finely chopped stalks, maize residues, sugar beet leaves, and waste from the untreated parts of plants.

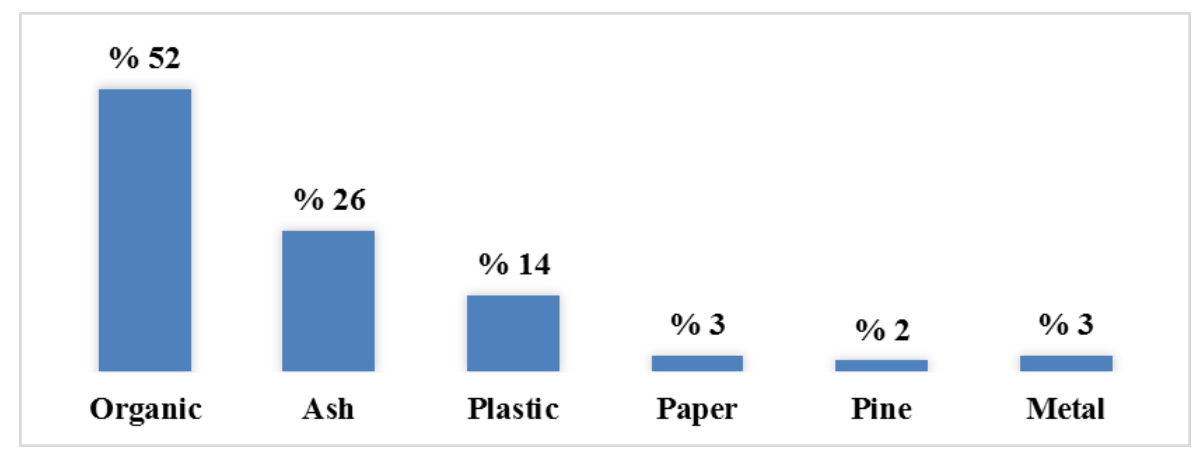

Figure 1. Waste Composition in Batman Province in 2017[13]

\subsection{Animal Wastes}

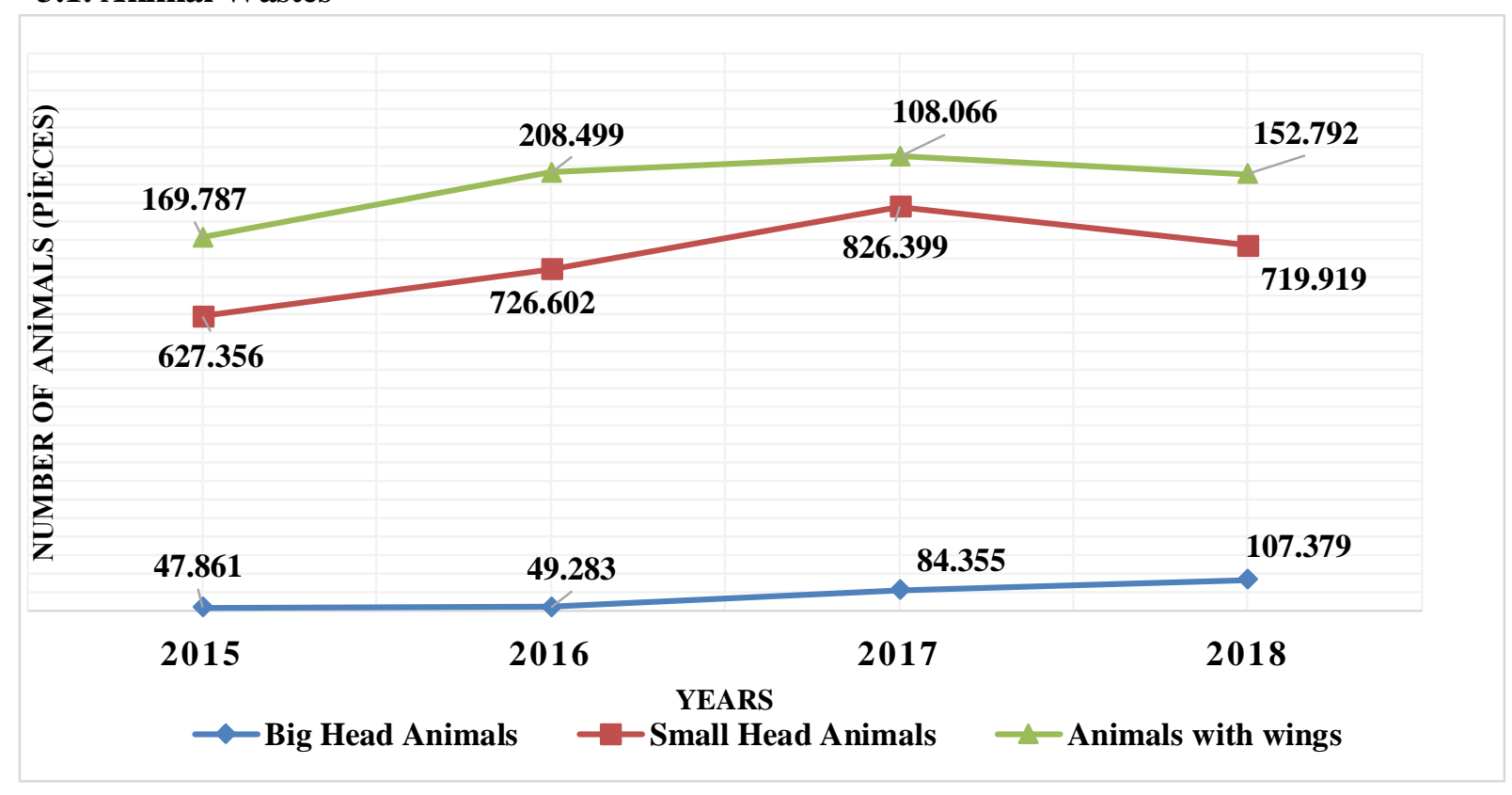

Figure- 2 Batman Province Animal Numbers by Years [14]

When we look at the statistical data of Batman province in animal husbandry field, in 2018, we see that most small small head animals (719.919) followed by animals with wings (152.792) and finally big head animals (107.379). When we look at the data of the last four years, it is observed that there is generally an increase in cattle and sheep and livestock breeding but there is a decrease in poultry husbandry. Table 1 below shows the number of animals on the basis of districts.

When the number of animals raised in Batman province is examined, it is seen that the number of big head animals in terms of biogas potential is less than the number of small head animals. According 
to the population density of Batman province, the majority of big head animals are raised in Kozluk and the majority of small cattle and poultry are grown in the central and central villages.

Table 1 Number of Cattle, Sheep and Poultry by Batman Province [14]

\begin{tabular}{|l|c|c|c|}
\hline District Name & Big Head Animals & Small Head Animals & Animals With Wings \\
\hline Merkez & 22.038 & 291.817 & 77.010 \\
\hline Beşiri & 6.861 & 163.286 & 53.350 \\
\hline Gercüş & 4.662 & 68.418 & 11.142 \\
\hline Hasankeyf & 1.095 & 17.380 & 140 \\
\hline Kozluk & 42.469 & 123.427 & 4.000 \\
\hline Sason & 30.254 & 55.591 & 7.150 \\
\hline Total & $\mathbf{1 0 7 . 3 7 9}$ & $\mathbf{7 1 9 . 9 1 9}$ & $\mathbf{1 5 2 . 7 9 2}$ \\
\hline
\end{tabular}

When the average amount of fertilizer and biogas obtained from animal sources is examined, 5$6 \%$ of the big head animals weight is obtained in $\mathrm{kg}$ fertilizer / day, while 4-5\% of sheep and goat weight is in $\mathrm{kg}$ fertilizer / day and 3-4\% in chicken weight. $3 \mathrm{~kg}$ of fertilizer / day can be obtained. [15]

In order to calculate the biogas potential, the research results are used in Table 2 below.

Table 2. Energy Quantities from Animal Wastes [15]

\begin{tabular}{|l|c|c|}
\hline \multicolumn{1}{|c|}{ Animal Type } & $\begin{array}{c}\text { Age Fertilizer } \\
\text { Tons / Year }\end{array}$ & $\begin{array}{c}\text { Biogas } \\
\mathbf{m}^{3} / \text { year }\end{array}$ \\
\hline Big Hed Animals & 3,6 & 33 \\
\hline Small Head Animals & 0,7 & 58 \\
\hline Animals With Wings & 0,022 & 78 \\
\hline
\end{tabular}

According to the data in the table according to the total number of animals in the province of Batman age fertilizer and biogas calculation;

For big head animals; $=386.564$ tons / year fertilizer,

For small head animals; 503.943 tons / year fertilizer,

For animals with wings ; 3.361 tons / year of manure was found.

When the results are obtained, it is seen that the maximum amount of fertilizer can be obtained from small head animals in Batman province. Although the amount of biogas can be obtained from big head animals according to the table, the majority of biogas production potential constitutes the amount of fertilizer that can be obtained from small head animals because of small animal husbandry production in Batman province.

When the biogas calculation can be obtained from these collected fertilizers;

For big head animals; $=12.756 .612 \mathrm{~m}^{3} /$ year or $34.949 \mathrm{~m}^{3} /$ day biogas

For small head animals; $=29.228 .694 \mathrm{~m}^{3} /$ year or $80.078 \mathrm{~m}^{3} /$ day biogas

For animals with wings; $=262.158 \mathrm{~m}^{3} /$ year or $718 \mathrm{~m}^{3} /$ day biogas was obtained. 
The daily energy amounts that can be obtained from $1 \mathrm{~m}^{3}$ biogas under normal conditions are shown in Table 3 [16]

Table 3. Thermal Values of Biogas

\begin{tabular}{|c|l|c|}
\hline \multirow{4}{*}{} & Quantity of heat & $4700-5700 \mathrm{kcal} / \mathrm{m}^{3}$ \\
\cline { 2 - 3 } & Oil & $0.62 \mathrm{lt}$ \\
\cline { 2 - 3 } Biogas & Wood Coal & $1.46 \mathrm{~kg}$ \\
\cline { 2 - 3 } & Wood & $3.47 \mathrm{~kg}$ \\
\cline { 2 - 3 } & Butane Gas & $0.43 \mathrm{~kg}$ \\
\cline { 2 - 3 } & Turd & $12.3 \mathrm{~kg}$ \\
\cline { 2 - 3 } & Electrical Energy & $4.70 \mathrm{kWh}$ \\
\cline { 2 - 3 } & Diesel & $0.66 \mathrm{lt}$ \\
\cline { 2 - 3 } & Gasoline & $0.75 \mathrm{lt}$ \\
\cline { 2 - 3 } & Propane & $0.25 \mathrm{~m}^{3}$ \\
\hline
\end{tabular}

$4.70 \mathrm{kWh}$ of electrical energy can be obtained from $1 \mathrm{~m}^{3}$ biogas. It was calculated that the total amount of biogas obtained from animal wastes for the province of Batman is converted into electrical energy and $544.000 \mathrm{KWh}$ of electricity can be obtained daily. Table 4 below shows the amount of biogas and energy that can be obtained daily in Batman province according to animal species.

Table 4. Biogas and Electricity Quantities Obtained from Animal Wastes in Batman Province

\begin{tabular}{|l|c|c|c|}
\hline \multicolumn{1}{|c|}{ Animal Type } & $\begin{array}{c}\text { Amount of Biogas } \\
(\mathbf{m 3 / d a y})\end{array}$ & $\begin{array}{c}\text { Electrical Energy } \\
(\mathbf{k W h} / \mathbf{d a y})\end{array}$ & $\begin{array}{c}\text { Available TL / day } \\
\text { Price }\end{array}$ \\
\hline Big Hed Animals & 34.949 & 164.260 & $73.917 \mathrm{TL}$ \\
\hline Small Head Animals & 80.078 & 376.366 & $169.364 \mathrm{TL}$ \\
\hline Animals With Wings & 718 & 3.374 & $1.518 \mathrm{TL}$ \\
\hline
\end{tabular}

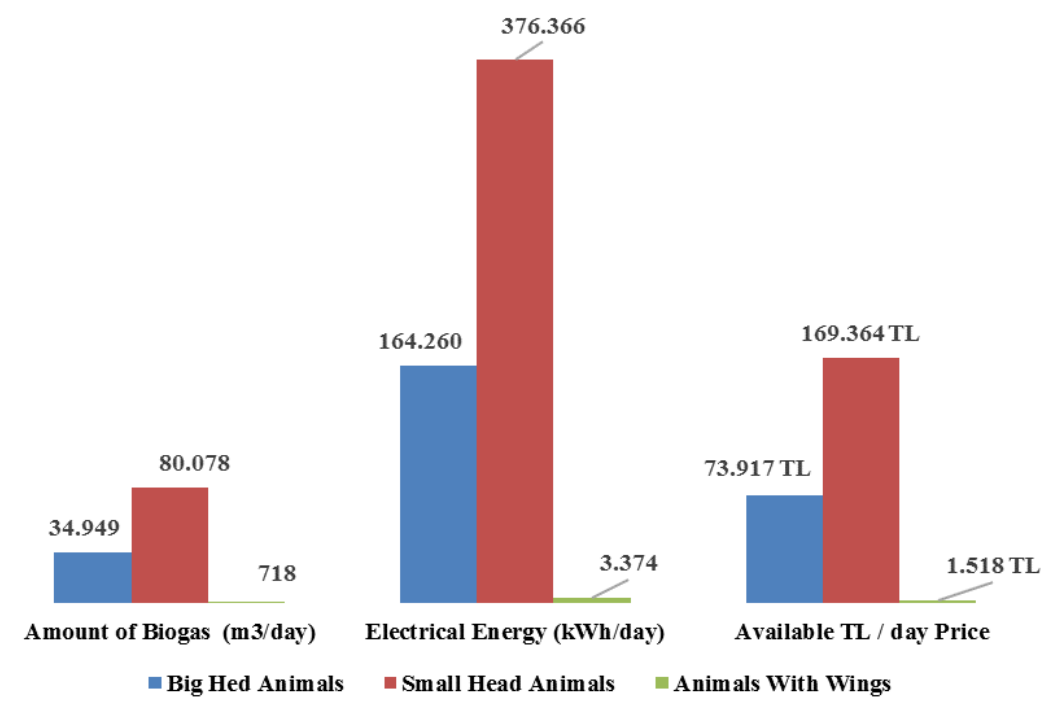

Figure-3 Biogas and Electricity Amounts Obtained from Animal Wastes for Batman Province 
Turkey Statistics $1 \mathrm{kWh}$ of electricity for the amount paid for housing, according to the Agency according to the average of 12:45 per month of June 2018 is. [17] According to the calculations, it was found that biogas from animal wastes would provide an economic contribution of approximately 244.799 TL in one day in Batman province.

When calculating the amount of biogas that can be obtained, the amount of energy that can be obtained if all of the organic wastes are collected is calculated. However, it is estimated that the loss rate will be around $30 \%$ when the fertilizers are collected in the pastures. When calculated according to this, the amount of energy that can be obtained daily in Batman province will be $380,800 \mathrm{KWh}$ electricity energy.

\subsection{Herbal Wastes}

According to the data obtained from Batman Agriculture and Livestock Provincial Directorate of Agriculture for the province of Batman, biogas potential and daily / annual energy analyzes obtained from vegetable wastes were calculated. The data and the results of the research given in Table 5 are used for this purpose.

Table 5. Batman Province Herbal Product Amounts [14]

\begin{tabular}{|l|l|c|c|c|}
\hline SN & Name of the product & Planted Area (da) & Yield (kg/da) & Production (ton) \\
\hline $\mathbf{1}$ & Egypt & 45.858 & 1446 & 66.353 \\
\hline $\mathbf{2}$ & Cotton (Mass) & 2.524 & 550 & 1.389 \\
\hline $\mathbf{3}$ & Corn Silage & 6.000 & 4825 & 28.950 \\
\hline $\mathbf{4}$ & Wheat & 64.862 & 375 & 24.346 \\
\hline $\mathbf{5}$ & Wheat Juicy & 23.245 & 638 & 14.839 \\
\hline $\mathbf{6}$ & Wheat Juicy & 32.423 & 519 & 16.835 \\
\hline $\mathbf{7}$ & Wheat (Other) Dry & 416.180 & 341 & 142.169 \\
\hline $\mathbf{8}$ & Barley (Other) Dry & 46.675 & 310 & 14.892 \\
\hline $\mathbf{9}$ & Red Lentils Dry & 141.031 & 191 & 26.945 \\
\hline $\mathbf{1 0}$ & Chickpeas Dry & 1.785 & 164 & 294 \\
\hline \multicolumn{2}{|r|}{ Sown Area Total } & 780.583 & & \\
\hline
\end{tabular}

The daily and annual production amounts of the biogas produced by the biogas calculation that can be obtained from the vegetable wastes collected in Batman province and the amount of daily and annual electricity energy of these products and the value added to be added to the country's economy are indicated in Table 6.

Approximately $10 \%$ of the total production amounts of wheat, corn, barley, chickpea and lentils are straw that can be used in biogas production. $1 \mathrm{~kg}$. about $0.017 \mathrm{~m}^{3}$ of biogas can be obtained daily from the straw. [18]

With these data, the biogas production of the agricultural products that can be used in the biogas production of Batman province is calculated; $1.563 \mathrm{~m}^{3} /$ day biogas will be obtained from the straw of the products such as corn, lentil, wheat, barley and chickpea. Approximately, $60 \%$ of the obtained biogas is composed of methane gas. This is equivalent to about $937.8 \mathrm{~m}^{3} /$ day of methane gas. $1 \mathrm{~m}^{3}$ of methane is $10 \mathrm{kWh}$ of energy. [18]

The daily and annual production amounts of the biogas produced when the biogas calculation can be obtained from the vegetable wastes to be collected in Batman province and the amount of daily and annual electricity energy of these products and their value added will be given in Table 6 . 
Table 6. Methane Gas and Electricity Quantities Obtained from Agricultural Wastes in Batman Province

\begin{tabular}{|c|c|c|c|c|c|c|}
\hline Agricultural Waste & \multicolumn{2}{|c|}{ Amount of Biogas } & \multicolumn{2}{c|}{ Electrical Energy } & \multicolumn{2}{c|}{ Available TL } \\
\hline $\begin{array}{c}\text { Corn, Wheat, Lentil, } \\
\text { Chickpea, Barley (Straw, }\end{array}$ & $\left(\mathrm{m}^{3} / \mathrm{day}\right.$ & $\left(\mathrm{m}^{3} /\right.$ year $)$ & $(\mathrm{kWh} / \mathrm{day})$ & $(\mathrm{kWh} / \mathrm{year})$ & $\begin{array}{c}\text { TL/day } \\
\text { Price }\end{array}$ & $\begin{array}{c}\text { TL/year } \\
\text { Price }\end{array}$ \\
\cline { 2 - 8 } & 1.563 & 570.495 & 7.346 & 2.681 .290 & 3.305 & 1.206 .580 \\
\hline
\end{tabular}

According to the calculations, a biogas production of approximately $3.305 \mathrm{TL}$ per day was calculated from vegetable wastes in Batman province.

According to the data in Table 6 , when the total vegetable waste and biogas calculation is done in Batman province;

Corn, Wheat, Lentil, Chickpea, Barley (Straw) $=335.593$ tons $/$ year

When the biogas calculation can be obtained from these products;

For Corn, Wheat, Lentil, Chickpea, Barley (Straw, Stalk); $=570.495 \mathrm{~m}^{3} /$ year or $1.563 \mathrm{~m}^{3} /$ day biogas will be obtained.

\section{RESULTS}

In this study, biogas potential of Batman province and cost analysis in terms of savings are examined. According to the results, it is seen that there will be a significant economic benefit in case of establishment of plants in biogas production when considering the animal waste potential and agricultural areas in Batman province. In Batman province, organic wastes (animal and vegetable) constitute the largest share in terms of waste materials. Biogas production will reduce the burning of buckets in the villages, stubble fires that cause serious environmental pollution will be prevented. In addition, fertilizers used in biogas plants will be used more economically in post-processing agricultural areas to provide an economic benefit..

As a result of researches, $52 \%$ of total wastes in Batman province are composed of organic wastes. According to the data obtained in the calculations; It has been found that the biogas production potential in Batman province is $115,745 \mathrm{~m}^{3}$ / day biogas and $544,000 \mathrm{KWh}$ / day electrical energy from vegetable wastes and 1,563 $\mathrm{m}^{3}$ / day biogas and 7,346 KWh / day electrical energy can be obtained from vegetable wastes. The results show that animal wastes are more advantageous in biogas production. However, the use of vegetable wastes as a source of biogas to transform both energy and rich fertilizers should not be ignored.

Our country is considered as an agricultural country in terms of its geographical location and economic structure. This potential needs to be evaluated and awareness raising should be established to increase biogas production. It is important to solve the energy problem of our country and to increase the renewable energy resources. At this point, more efficient use of solid wastes for biogas production will be useful.

\section{REFERANCES}

[1] Mao C, Feng Y, Wang X, Ren G. "Review on research achievements of biogas from anaerobic digestion". Renewable and Sustainable Energy Reviews, 45, 540-555, 2015.

[2] Speece RE. Anaerobic Biotechnology for Industrial Wastewater., Tennesse, USA, Arche Press 1996. 
[3] Deublein D, Steinhauser A. Biogas from Waste and Renewable Resources, ISBN: 978-3-52732798-0, Weinheim, Germany, Wiley, 2008.

[4] Marmara regions Magazine Issue 30, July - 2014 S.97-125 world and in Turkey Usage Status of Biomass Energy

[5] Y. Ulusoy, H. Ünal ve K. Alibaş, “Biyogaz Üretimi Prosesi”, Uludağ Üniversitesi, Bursa.

[6] Balat, M. (2005). "Use Of Biomass Sources For Energy In Turkey And AView To Biomass Potential", Biomass and Bioenergy, Number: 29(2005,) p. 32-41.

[7] Adem Y., Sinan Ü., Tufan K.,Abdulkadir K. Biogas Production and Biogas Production Statistics Information in Turkey ISS-2017

[8] Arıkan B. Investigation of the Efficiency of Biogas Production in Anaerobic Environment from Organic Domestic Solid Wastes. Master Thesis, Çukurova University, Adana, Turkey, 2008

[9] Özcan M, Öztürk S, Yıldırım M. "Determination of the biogas potential according to different resource types in Turkey”. Energy Efficiency and Quality Symposium, Kocaeli, Turkey, 12-13 May 2011

[10] Altıkat S. Çelik A. "Biogas potential from animal waste of ığdır province”. Iğdır University. Journal of Graduate School of Natural and Applied Sciences, 2(1), 61-66, 2012

[11] Nilüfer Nacar Koçer, Gizem Kurt Livestock potential and biogas production in Malatya. Sakarya University Journal of Science 17. Skin, 1. Number, s. 1-8, 2013 SAU J. Sci. Vol 17, No 1, p. 1-8, 2013

[12] Halil ŞENOL, Emre Aşkın ELİBOL, Ünsal AÇIKEL, Merve ŞENOL Main Organic Waste Sources of Ankara for Biogas Production BEU Journal of Science 6(2), 15-28, 2017

[13] Batman Provincial Directorate of Environment and Urbanization, Environmental Situation Report 2017, pp 29

[14] Statistics Report of Batman Provincial Directorate of Agriculture, 2018

[15] http://www.yegm.gov.tr/yenilenebilir/biyogaz.aspx date access: 20.10.2018

[16] http://www.enerji.gov.tr/tr-TR/sayfalar/biyokutle date accsess: 21.10.2018

[17] http://tuik.gov.tr/PreHaberBultenleri.do?id=27666 date accsess: 21.10.2018

[18] Akbulut, A., Dikici, A., (2004). Biogas Potential and Cost Analysis of Elazig Province, Eastern Anatolia Region. 